\title{
Convergence Of US-GAAP And International Standards: The Critical Issues
}

Steven W. Smalt (Email: steve_smalt@coles2.kennesaw.edu), Kennesaw State University, USA John P. McAllister, Kennesaw State University, USA

\begin{abstract}
This paper provides readers with:

1) An update on an institutional change that will focus the attention of worldwide accounting and financial reporting standard setters on the convergence of international and national standards, and

2) An analysis of "in-process" issues in the international accounting arena that will be critical to the success / failure of this convergence effort.
\end{abstract}

\section{Institutional Change}

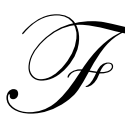

rom its beginnings in the mid 1970s, the Board of the International Accounting Standards Committee (IASC) promulgated International Accounting Standards (IAS). This 13-member (all part-time) Board represented professional accounting groups from member countries. The total number of IASC member countries had grown from the 10 charter members to 134 at the end of 2000.

Effective April 1, 2001, the Board of the IASC handed over responsibility for setting IAS to a new Board appointed by the newly established IASC Trustees. For an extensive chronicle of this momentous change, please refer to "The New Structure for International Accounting Standards" by Mary Ellen Oliverio (The CPA Journal, May 2000, pages 20-26 and 91).

In accordance with the IASC's new constitution, the new International Accounting Standards Board (IASB) is comprised of 14 individuals (12 full-time members) as follows:

- $\quad$ A minimum of five with a background as practicing auditors

- A minimum of three with a background in the preparation of financial statements

- A minimum of three with a background as users of financial statements

- $\quad$ At least one member with an academic background

- $\quad$ Seven of the full-time members will be expected to have formal liaison responsibilities with national standard setters in order to promote the convergence of national accounting standards and IAS (emphasis added).

How Likely is it that National Accounting Standards and International Accounting Standards Will Converge?

Seven liaison Board members actively seeking input from national standard-setting bodies should enhance the likelihood of national and international standard convergence. Furthermore, the IASC Board clearly indicated

Readers with comments or questions are encouraged to contact the authors via email. 
that convergence of national and international standards is the theme for the future for global accounting standards:

The path established by IASC's restructuring decisions for achieving agreement on global accounting standards is through convergence of national and international standards (emphasis added). (IASC Annual Review 2000, page 8).

Considering this, it is not surprising that the outgoing Board of the IASC offered suggestions and advice to the new IASB; 18 issues were identified that it apparently viewed as important to the convergence effort. Some of these were actually on the IASC's final agenda and others were proposals for new projects under consideration.

\section{Analysis of "In-Process" Issues}

We have selected the seven issues (of the 18 identified by the IASC) that, in our opinion, will be most important to the convergence effort. The issues/topics (in alphabetical order) are:

1. Accounting for share-based payments

2. Business Combinations (including Goodwill)

3. Discounting and fair values

4. $\quad$ Framework (concepts)

5. Regulation to secure effective application of IAS

6. $\quad$ Reporting Financial Performance

7. Reporting on narrative discussions outside the notes to the financial statements.

For each issue, we will discuss:

- $\quad$ why its resolution is critical to convergence

- $\quad$ treatments currently called for under US-GAAP and IAS, and

- $\quad$ our opinion as to the resolution of the issue that would be the 'best' to improve the quality of worldwide financial reporting (i.e., encourage convergence).

\section{Accounting for Share-Based Payments (specifically, stock option plans)}

Why Resolution Is Critical to Convergence

We see this issue as critical to convergence because of the importance of these compensation schemes to an ever-growing majority of companies. Once a primarily US issue, this has become an international issue coincidental with the increase in the number of companies around the world that have become capital market participants.

This issue is especially important, in our view, because of the negative impact on company credibility caused when there is even a hint of suspicion about the compensation of key executives.

\section{Current US and IAS Treatments}

US-GAAP allows companies to choose between including the cost of share-based in the determination of net income and disclosing that cost in the notes to the financial statements. There is no existing IAS that addresses this issue.

\section{What Would Be "Best" for Convergence?}

We believe that a common standard for US-GAAP and IAS is definitely in order. In the US, accounting in this area has been highly contentious for over 10 years. This is one area where leadership by the IASB might benefit the FASB in that it would assist in "jumping over" some highly political hurdles. 


\section{Business Combinations (including Goodwill)}

\section{Why Resolution Is Critical to Convergence}

Business combinations occur more and more frequently every year. Furthermore, it is through these combinations that the problematic asset Goodwill presents itself. As with accounting for share-based payments, any lack of uniformity in accounting in these areas is poor public relations for companies and auditors. This is especially true in recent years, as we have seen an unfortunate number of business combinations result in less than desirable outcomes.

Accounting for the combination (purchase versus pooling), what percentage of voting shares triggers consolidation, and the initial recognition and future treatment of Goodwill are rich issues for which common worldwide answers will truly improve financial reporting.

\section{Current US and IAS Treatments}

As we write this paper, both IAS and US-GAAP allow both purchase and pooling-of interest accounting. Both regimes require amortization of Goodwill over periods of time, with the US allowing up to 40 years and the IAS allowing up to 20 years. Under IAS, consolidation is called for in cases where one entity controls the other. Under US-GAAP, ownership in excess of $50 \%$ of voting shares calls for consolidation.

What Would Be "Best" for Convergence?

There seems to be reasonable consensus around the world that the pooling of interests method should be disallowed, thus resulting in all combinations being treated under purchase accounting. With respect to Goodwill, a choice must be made between amortization over an agreed upon number of years and no amortization. The latter would necessitate annual consideration of impairment.

\section{Discounting and Fair Values}

\section{Why Resolution Is Critical to Convergence}

Historical cost versus current values - the seemingly endless debate for accounting theoreticians - never seems to go away! While in years gone by this was a fascinating topic within any country, its resolution within a particular country would not affect other countries. Unfortunately, that is no longer the case. Fundamental differences in measurement are simply not acceptable as we move into an economic world with no real borders. While it may be that the solution could be different depending upon the nature of the item (monetary versus at fair vale, non-monetary at historical cost, for example), at least some level of commonality is definitely required.

Many, if not most, business decisions are made using discounting as a measurement tool. It makes sense that financial reporting also use discounting as a key tool in value measurement.

\section{Current US and IAS Treatments}

Both US-GAAP and IAS are guilty of being all over the place on this one. Fair values are required in some areas, but not in others.

What Would Be "Best" for Convergence?

Convergence would be best served, in our view, by stipulating that all monetary assets and liabilities (financial instruments) should be included in balance sheets at fair value. On the other hand, non-monetary items (land, buildings, etc.) should continue, for the foreseeable future, to be presented at their historical cost, less depreciation and impairments. 


\section{Framework (concepts)}

Why Resolution Is Critical to Convergence

Both the FASB's Statements of Financial Accounting Concepts (often referred to as the Conceptual Framework) and the IASB's Framework for the Preparation and Presentation of Financial Statements include the claim that their major purpose is to guide standard setting. Most practitioners (auditors and preparers) have little use for these frameworks as they focus most of their attention on the standards themselves. It makes sense then that the primary audience for frameworks would be those who seek to establish standards.

Convergence will be much more likely if the standard setters are referring to similar (if not the same) concepts.

\section{Current US and IAS Treatments}

For a comprehensive assessment of the differences between the US and IAS concepts, please refer to "Obstacles to International Accounting Standards Convergence" by J. Campbell, H. Hermanson and J. McAllister (CPA Journal, May 2002, pages 21-24).

What Would Be "Best" for Convergence

Convergence would be best served if agreement could be reached on a set of concepts. As noted in the above-referenced Campbell paper, the FASB and IAS frameworks have significant areas of agreement. Hence, we believe that eliminating the differences would truly facilitate convergence.

\section{Regulation Re: Application of IAS}

\section{Why Resolution Is Critical to Convergence}

No matter how good any set of standards is, they are meaningless if preparers of financial statements do not comply with such standards. This issue probably seems strange to US readers because we have long assumed that standards are applied considering the presence of the SEC and auditors. Apparently this is not always the case with the application of IAS. Clearly IAS financials will have little credibility if 'rumor' has it that IAS are selectively applied and that security market regulators and / or auditors simply 'look the other way.'

Current US and IAS Treatments (not relevant to this issue)

What Would Be "Best" for Convergence (not relevant to this issue)

\section{Reporting Financial Performance}

Why Resolution Is Critical to Convergence

Yes, it is true that there are three major financial statements (balance sheet, income statement, statement of cash flows). However, there is virtually no question as to which one gets the most attention. Everyone wants to know about performance and accounting's performance statement is the income statement. Despite this common center of attention, there is not so much agreement when it comes to details. Popular points of focus include operating income, EBITDA, EBITA, and EBIT. Complications present themselves in the form of extraordinary items, accounting changes, gains / losses on discontinued operations. Furthermore, there are differing views as to whether or performance measurement should be comprehensive (including all changes in equity) or something less than that. 
Agreement on a common measurement of performance measurement will be critical to having across the board acceptance of financial reporting.

Current US and IAS Treatments

Both US-GAAP and IAS use what might be thought of as traditional formats for income statements. Both regimes also have special requirements to extend traditional net income to a more inclusive measurement. Under US-GAAP this is referred to as "comprehensive income" and may be presented in several manners.

What Would Be "Best" for Convergence

Both the FASB and the IASB are working on projects intended to reconsider the format and inclusiveness of the income statement. Because of the dominating concern worldwide regarding performance of companies, convergence would be best served by reaching a common conclusion in this area. Of particular interest are proposals under both regimes to segment the income statement into sections similar to the statement of cash flows (operating, financing and investing).

\section{Reporting on Narrative Disclosures Outside the Notes to the Financial Statements}

Why Resolution Is Critical to Convergence

As there is no question that we work in an age of information, there is also no question that financial reporting and auditing cannot hide from this reality. We can no longer limit our focus to the financial statements and the notes to those statements. Why? Readers need information that is both relevant to their decision-making and sufficiently reliable. They do not want to hear about any unnatural borders between information that may serve the needs of the preparers and auditors, but no one else.

Current US and IAS Treatments (not relevant to this issue)

What Would Be "Best" for Convergence

Convergence will be best served by establishing common borders in this area. As security exchanges become more centralized it makes sense that there not be differences in the "reach" over which financial reporting extends.

\section{References}

1. $\quad$ Oliverio, M.E., "The New Structure for International Accounting Standards." The CPA Journal, May 2000, pages 20-26 and 91 .

2. Campbell, J., H. Hermanson, J. McAllister, "Obstacles to International Accounting Standards Convergence." The CPA Journal, May 2002, pages 21-24. 
Notes 